\title{
Review: Leptospirosis pada Anjing di Indonesia
}

\author{
Review: Leptospirosis in Dogs in Indonesia \\ Rifen Prabawan Krida Taruna Wiyata ${ }^{1}$, Widi Nugroho ${ }^{1 *}$ \\ ${ }^{1}$ Laboratorium Kesehatan Masyarakat Veteriner, Fakultas Kedokteran Hewan, Universitas \\ Brawijaya
}

*Email : widi.nugroho@ub.ac.id

\begin{abstract}
ABSTRAK
Leptospirosis ialah penyakit infeksius yang diakibatkan oleh bakteri motil dari genus Leptospira. Prevalensi leptospirosis pada anjing di Indonesia berkisar 13,8\% - 44\% dengan varian Leptospira antara lain serovar Ichterohaemorrhagiae, Celledoni, Canicola, Pyrogenes, Cynopteri, Rachmati, Bataviae, Javanica, Grippotyphosa dan Tarrasovi. Leptospira sp. dapat ditularkan melalui kontak langsung atau melalui tanah dan air yang terkontaminasi Leptospira sp. Hewan pengerat, babi, kuda, hewan ternak, anjing dan berbagai hewan liar seperti tupai dan rusa dapat berperan sebagai karier Leptospira. Gejala klinis leptospirosis pada anjing di Indonesia berupa demam, letargi, anoreksia, muntah, ikterus, gangguan ginjal, dispnea, poliuria, urin berwarna kuning, dehidrasi dan kematian. Gold standard pengujian leptospirosis pada anjing adalah MAT, namun uji PCR dan ELISA memiliki sensitivitas yang lebih tinggi. Upaya pencegahan kejadian leptospirosis dilakukan dengan vaksinasi, penggunaan disinfeksi rutin pada lingkungan kandang dan mencegah anjing kontak langsung dengan hewan reservoir seperti tikus.
\end{abstract}

Kata Kunci: anjing, Leptospira sp., leptospirosis

\begin{abstract}
Leptospirosis is an infectious disease caused by motile bacteria of the genus Leptospira. The prevalence of leptospirosis in dogs in Indonesia ranges from 13,8\% - 44\%, with Leptospira variants including the serovars Ichterohaemorragiae, Celledoni, Canicola, Pyrogenes, Cynopteri, Rachmati, Bataviae, Javanica, Grippotyphosa and Tarrasovi. Leptospira sp. can be transmitted through direct contact with an infected animal, soil or water contaminated with Leptospira sp. Rodents, pigs, horses, farm animals, dogs and various wild animals such as squirrels and deer can serve as carriers of Leptospira sp. Clinical symptoms of leptospirosis in dogs in Indonesia include fever, lethargy, anorexia, vomiting, jaundice, kidney disorders, dyspnea, polyuria, yellow urine, dehydration and death. The gold standard for leptospirosis testing in dogs is the MAT test, but the PCR and ELISA tests have higher sensitivity. Prevention of leptospirosis in dogs can be done by vaccination, routine disinfection of dog house and preventing dogs from direct contact with reservoir animals such as rats.
\end{abstract}

Keywords : dogs, Leptospira sp., leptospirosis

\section{PENDAHULUAN}

Leptospirosis ialah penyakit infeksius yang menyerang hewan dan manusia. Penyakit ini disebabkan oleh bakteri motil yang berasal dari genus Leptospira
(Goldstein, 2010). Leptospirosis tersebar pada berbagai negara di dunia khususnya pada daerah dengan iklim tropis maupun subtropis yang memiliki curah hujan tinggi, seperti Indonesia. Bakteri ini bisa hidup dan berkembang pada ginjal hewan 
reservoir, selanjutnya akan ikut dibuang bersama urin sehingga dapat mencemari lingkungan. Leptospira sp. akan memasuki inang melalui ingesti air yang tercemar leptospira, penetrasi melalui luka terbuka, dan melalui selaput lendir yaitu konjungtiva, mulut, atau genital (Kurilung et al., 2017). Individu yang terjangkit leptospirosis dapat menunjukkan gejala ringan sampai berat bahkan kematian.

Anjing ialah salah satu hewan reservoir Leptospira sp. Anjing dengan penyakit leptospirosis ditemukan pertama kali tahun 1899. Leptospira interrogans serovar Canicola dan Icterohaemorrhagiae ialah spesies utama yang menginfeksi anjing (Kusmiyati et al., 2005). Leptospirosis merupakan penyakit yang dapat menimbulkan infeksi berat hingga kematian pada anjing dan berpotensi ditularkan ke manusia. Review ini bertujuan menampilkan informasi terkini tentang leptospirosis pada anjing, yang dapat menjadi referensi untuk meningkatkan kualitas diagnosa, pencegahan, pengobatan dan upaya pengendalian leptospirosis pada anjing di Indonesia.

\section{METODE}

Metode yang digunakan pada penulisan review ini yaitu pengumpulan data berupa artikel leptospirosis pada anjing di Indonesia pada tahun 1990 2021 dan artikel internasional yang membahas mengenai leptospirosis pada anjing di berbagai negara di dunia. Artikel diakses pada database Google Scholar dengan kata kunci pencarian yaitu: "leptospirosis", "leptospirosis pada anjing di Indonesia", "Canine leptospirosis", dan "Leptospirosis in dogs". Analisis data dikerjakan secara deskriptif.

\section{LEPTOSPIROSIS}

Leptospirosis ialah penyakit menular dan zoonosis yang tersebar pada berbagai negara di dunia. Penyebabnya yaitu bakteri dari ordo Spirochaetales, famili Leptospiraceae dan genus Leptospira (Mishima et al., 2013). Leptospira ialah bakteri Gram negatif, motil, memanjang, berbentuk melingkar seperti heliks (Gambar 1) (Schuller et al., 2015). Bakteri ini memiliki ketebalan $0,1 \mu \mathrm{m}$ serta panjang 6-20 $\mu \mathrm{m}$ (Johnson and Johnson, 2018). Leptosipra sp. adalah bakteri obligat aerob, yang membutuhkan oksigen untuk bertahan hidup (Ramadhani dan Yunianto, 2012). Bakteri ini dapat bertahan hidup selama 3 minggu hingga berbulan-bulan tergantung dari kondisi lingkungan dan spesies (Bierque et al., 2020). Leptospira alstonii misalnya, dapat bertahan selama lima bulan di tanah pada kedalaman tiga centimeter pada kelembaban $7,8 \%$ (Saito et al., 2013). Leptospira interrorgan dapat bertahan hidup pada tanah di lingkungan tropis hingga 9 minggu (Thibeaux et al., 2017). Leptospira sp. dapat diklasifikasikan menjadi Leptospira patogen (L. interrogan) dan Leptospira saprofitik (L. biflexa) (Mohammed et al., 2011). Kedua klasifikasi ini dikembangkan lebih jauh menjadi serovar spesifik berdasarkan adanya antigen homolog (60 serovar turunan L. biflexa dan 225 serovar turunan $L$. interrogans). Lebih dari 21 spesies turunan Leptospira telah diidentifikasi dengan lebih dari 200 
serovar (Mohammed et al., 2011). Klasifikasi leptospira dibagi menjadi tiga berdasarkan kemampuan menyebabkan penyakit yaitu leptospira patogen, saprofitik, dan intermediate (patogenisitas belum jelas) (Samrot et al., 2021).

Leptospira saprofitik mampu tumbuh pada suhu rendah $\left(5-35^{\circ} \mathrm{C}\right)$, dapat ditemukan secara alami di tanah dan air, serta tidak memiliki kemampuan untuk menyebabkan infeksi (Samrot et al., 2021). Bakteri ini biasanya berada pada tanah lembab atau permukaan air namun jarang ditemukan pada manusia dan hewan lain (Benacer et al., 2013). Leptospira biflexa merupakan leptospira golongan saprofitik yang pertama kali diidentifikasi. Leptospira saprofitik lainnya diantaranya adalah $L$. wolbachii, L. meyeri, L. terpstrae, L. vanthielli, dan L. yanagawae (Bulach et al., 2006).

Leptospira intermediate merupakan leptospira yang status patogenesitasnya belum diketahui secara jelas (Pui et al., 2017). Spesies leptospira dari kelompok intermediate antara lain $L$. inadai, $L$. licerasiae, L. broomi, L. Fainei dan $L$. Wolffii (Chaiwattanarungruengpaisan et al., 2018). Salah satu contoh leptospira intermediate adalah Leptospira licerasiae serovar Varillal. Leptospira licerasiae serovar Varillal memiliki sifat yang mirip dengan leptospira patogen yaitu peka terhadap 8-azaguanine, memiliki protein yang terkait LipL32 berdasarkan uji Western dan Southern blot, namun tidak mengandung Gen terkait LigA berdasarkan uji Southern blot. (Matthias et al., 2008). Berbeda dengan $L$. interrogans, Leptospira licerasiae serovar Varillal dapat tumbuh cepat (mirip dengan L. biflexa) tapi tidak menyebabkan penyakit pada hewan yang terinfeksi secara eksperimental.

Leptospira patogen membutuhkan suhu berkisar antara $20-35^{\circ} \mathrm{C}$ untuk tumbuh, umumnya dapat ditemukan pada rodensia dan memiliki flagela dengan struktur menyerupai bakteri Gram negatif (Benacer et al., 2013). Beberapa spesies pada kelompok ini antara lain termasuk $L$. weilii, L. santarosai, L. kirschneri, $L$. interrogans, L. borgpetersenii, dan $L$. noguchii (dos Santos et al., 2017). Kelompok ini mampu menyebabkan leptospirosis pada hewan dan manusia hingga menimbulkan morbiditas dan mortalitas (Samrot et al., 2021).

Leptospira sp. dapat beradaptasi pada satu hewan mamalia atau lebih, baik sebagai inang definitif atau reservoir. Pada inang reservoir akan terjadi infeksi persisten dengan gejala klinis ringan dan bakteri akan dikeluarkan bersama urin selama berbulan-bulan hingga bertahuntahun. Anjing merupakan hewan yang dapat bertindak sebagai inang reservoir untuk Leptospira interrogan serovar Canicola (Goldstein, 2010). Kejadian leptospirosis pertama kali pada anjing ditemukan di tahun 1899. Serovarian yang paling umum menyebabkan Leptospirosis pada anjing adalah Leptospira serovar canicola, Icterohaemorrhagiae, Grippothyposa, Pomona dan Bratislava (Adin dan Cowgill 2000). Leptospira interrogans serovar Canicola dan Icterohaemorrhagiae ialah spesies utama yang menginfeksi anjing (Goldstein, 2010), babi, kuda, sapi, domba serta tikus (Ellis, 2015). Indonesia memiliki 14 serovar standar uji leptospirosis pada hewan dan manusia, antara lain serovar 
Ichterohaemorrhagiae,

Pyrogenes, Hardjo,

Celledoni,

Cynopeteri, Ballum, Grippotyphosa, Pomona, Australis, Tarrasovi, Canicola, Javanica, dan Bataviae (Mulyani et al., 2017).

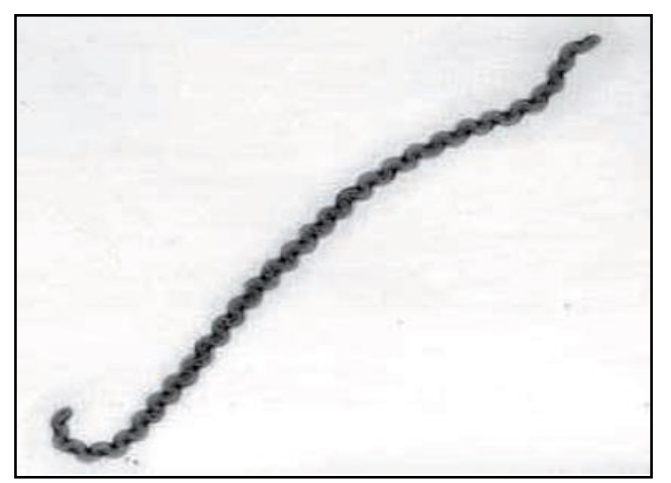

Gambar 1. Leptospira sp. (Ko et al., 2009)

\section{GEJALA KLINIS LEPTOSPIROSIS PADA ANJING}

Gejala klinis leptospirosis pada anjing bervariasi, mulai dari subklinis hingga menimbulkan kematian, tergantung umur, respon imun inang, dan virulensi mikroba (Levett et al., 2001). Gejala klinis leptospirosis yang dilaporkan pada anjing di Indonesia antara lain demam, letargi, anoreksia, muntah, ikterus, gangguan ginjal, dispnea, poliuria, urin berwarna kuning, dehidrasi, dan kematian (Mulyani et al., 2017; Prasetyo dan Pamungkas ,2018; Winaya et al., 2018). Gejala klinis leptospirosis fase akut pada anjing didominasi acute kidney injury (AKI) dan gangguan hati. Manifestasi utama leptospirosis pada anjing $(\mathrm{n}=256)$ meliputi kerusakan ginjal 99,6\%, paruparu $76,7 \%$, hati $26,0 \%$, dan sindrom hemoragik 18,2\% (Major et al., 2014). Infeksi leptospira pada anjing dapat menyebabkan kematian dengan presentase sebesar 28-70\% (Kohn et al., 2010).

Gejala klinis leptospirosis pada anjing berupa demam dapat terjadi pada fase awal penyakit disertai dengan lemah dan keengganan bergerak (Kohn et al., 2010). Tanda klinis yang berhubungan dengan gangguan ginjal yaitu poliuria (PU) dan polidipsia (PD) dengan atau tanpa azotemia dan olirugia/anuria (Major et al., 2014). Tanda klinis pernapasan dapat berupa takipnea dan dispnea ringan hingga berat (Kohn et al., 2010). Manifestasi pada jantung menunjukkan takiaritmia ventrikel dan kerusakan miokardia (Mastrorilli et al., 2007). Pankreatitis dapat terjadi pada anjing yang mengalami leptospirosis akut dan mengakibatkan munculnya tanda-tanda kesakitan pada perut, anoreksia dan muntah (Schuller et al., 2015). Leptospirosis pada anjing juga dapat menunjukkan gejala optalmologis antara lain peningkatan lakrimasi, leleran mukopurulen, pan-uveitis, konjungtivitis, berkurangnya reflek pupil, ablasi retina dan perdarahan retina (Townsend et al., 2006). Anjing yang mengalami kondisi leptospirosis juga dapat mengalami perdarahan seperti hemoptisis, epistaksis, hematemesis, haematochezia, melaena, haematuria dan petechiae (Kohn et al., 2010).

Leptospira sp. juga menginfeksi hati sehingga mengakibatkan gangguan pada hati, baik gangguan hati ringan yang ditandai dengan peningkatan enzim-enzim hati dan gangguan hati parah yang ditandai dengan adanya hepatic encephalopathy (Schuller et al., 2015). Gangguan ini mengakibatkan hati tidak dapat mengkonjugasi bilirubin, sehingga 
bilirubin akan dilepaskan kembali menuju aliran darah. Jumlah bilirubin dalam darah yang melebihi batas nilai normal (hiperbilirubinemia) akan mengakibatkan timbulnya gejala ikterus. Oleh karena itu pada beberapa kasus leptospirosis dapat ditemui gejala ikterus, terutama pada kasus leptospirosis dengan gangguan hati parah (Greene, 2012).

\section{PENULARAN LEPTOSPIRA SP. PADA ANJING}

Penularan Leptospira sp. dapat terjadi melalui dua cara yaitu langsung dan tidak langsung. Penularan yang terjadi secara langsung dapat melalui kontak langsung dengan urin, venereal, trans plasenta, gigitan atau konsumsi makanan atau minuman yang tercemar Leptospira sp. Penularan secara tidak langsung yaitu berasal dari tanah dan air lingkungan yang tercemar urin dari hewan terinfeksi Leptospira sp. (Goldstein, 2010). Penularan leptospira juga dapat terjadi penetrasi melalui luka terbuka, dan melalui selaput lendir (konjungtiva, mulut, atau genital) (Kurilung et al., 2017). Hewan pengerat, babi, kuda, hewan ternak, anjing dan berbagai hewan liar seperti tupai, dan rusa adalah beberapa hewan yang menjadi karier dari Leptospira sp. (Samrot et al., 2021). Bakteri ini akan berkoloni pada tubulus proksimal ginjal, berkembang biak dengan cepat dan sebagian akan dieksresikan ke lingkungan melalui urin (Kurilung et al., 2017).

\section{PATOGENESIS PADA ANJING}

Proses masuknya agen leptospirosis dapat terjadi pada saat minum, berenang, atau berjalan di atas genangan air yang tercemar Leptospira sp. (Ellis, 2015). Selain itu Leptospira sp. juga dapat memasuki inang melalui luka terbuka, konjungtiva, selaput lendir atau genital tract (Mohammed et al., 2011). Mekanisme molekuler patogenesis leptospirosis masih belum jelas. Beberapa faktor virulensi patogenesis Leptospira antara lain Lipopolisakarida (LPS), hemolisin, Outer Membrane Proteins (OMPs), serta molekul adhesi (Evangelista and Coburn, 2011). Leptospira patogen mengekspresikan sejumlah protein seperti LigA, LigB dan LigC yang mengandung domain mirip imunoglobulin. Baik LigA dan LigB mengikat komponen membran ekstraseluler inang, seperti elastin, tropoelastin, kolagen I dan IV, laminin, dan terutama fibronektin. Selain itu juga terdapat LipL32 dalam spesies leptospira patogen, namun tidak ditemukan pada spesies non-patogen. OMP leptospira utama ini mengikat kolagen I, IV dan V, serta laminin dan fibronektin (Evangelista and Coburn, 2011). Beberapa protein inang dapat mengikat banyak protein leptospira dan setidaknya 20 protein leptospira berikatan dengan laminin. LipL32 dan LigB merupakan faktor virulensi dan mempunyai kapasitas pengikatan terhadap komponen inang (Adler dan Klaasen, 2015).

Setelah melekat pada inang, bakteri memasuki pembuluh darah, merusak endotel pembuluh darah dan mengakibatkan sel mengalami ekstravasasi dan perdarahan. Leptospira $s p$. memiliki flagela periplasmik yang memungkinkan untuk memasuki aliran darah inang hanya dalam beberapa menit. 
Tahap awal (fase akut) dari infeksi leptospira ini disebut juga fase leptospiraemia, non-ikterik atau bakteremia (Samrot et al., 2021). Bakteri ikut tersebar melalui aliran darah ke seluruh tubuh dan tersebar ke berbagai organ seperti ginjal, sistem saraf pusat, mata, hati, limpa serta organ reproduksi. Setelah jumlah Leptospira sp. dalam darah dan jaringan mencapai tingkat tertentu, endotoksin berupa LPS akan mengakibatkan kerusakan jaringan dan gejala klinis akan muncul (Mohammed et al., 2011).

Masa inkubasi leptospirosis tergantung pada dosis infektif, kecepatan pertumbuhan organisme, toksisitas, dan kekebalan hospes. Studi eksperimental memperlihatkan bahwa masa inkubasi Leptospira sp. hingga munculnya gejala klinis seperti demam, lesu dan anoreksia yaitu sekitar tujuh hari, namun bervariasi tergantung respon imun dari inang serta dosis dan serovar yang menginfeksi ((Greenlee et al., 2005). Respon kekebalan humoral terjadi pada minggu pertama infeksi, selanjutnya makrofag dan neutrofil akan melakukan fagositosis. Saat Leptospira sp. berikatan dengan sel inang, sitokin (interleukin-6, interleukin10 dan TNF-) dan Antimicroba Peptids (AMPs) dilepaskan untuk membatasi kerusakan invasif yang ditimbulkan oleh bakteri (Cagliero et al., 2018). Meskipun telah ditelan oleh sel fagositik, leptospira mampu bereplikasi dan bertahan hidup pada fagolisosom. Di lain sisi, sistem kekebalan tubuh inang akan secara terus menerus melepaskan sitokin dalam jumlah yang berlebihan (Cagliero et al., 2018). Leptospira sp. yang berada pada ginjal akan sulit dimusnahkan, terutama pada bagian glomerulus yang jarang terdapat antibodi, hal tersebut dikarenakan antibodi memiliki ukuran yang cukup besar sehingga tidak bisa melalui filtrat glomerulus.

\section{DIAGNOSIS LEPTOSPIROSIS PADA ANJING DI INDONESIA}

$\begin{array}{ccr}\text { Diagnosis } & \begin{array}{c}\text { leptospirosis } \\ \text { sinyalmen, }\end{array} & \begin{array}{r}\text { dicapai } \\ \text { anamnesa, }\end{array} \\ \text { melalui } & \text { fisik serta } & \text { diagnosa } \\ \text { emeriksaan } & \text { definitif } \\ \text { enunjang. } & \text { Diagnosis } & \text { defing }\end{array}$
leptospirosis sering menemui beberapa kesulitan. Kesulitan pertama yang harus dihadapi yaitu tanda klinis penyakit ini seringkali tidak jelas. Data klinikopatologi seringkali merupakan kerusakan suatu organ dan biasanya nonspesifik (Goldstein, 2010). Pemeriksaan laboratorium untuk leptospirosis umumnya menggunakan uji serologi, terutama untuk kasus akut. Pemeriksaan penunjang yang telah dilaporkan untuk mendiagnosa leptospirosis pada anjing di Indonesia antara lain uji hematologi dan kimia darah (Prasetyo dan Pamungkas, 2018), MAT (Mutawadiah et al., 2015; Mulyani et al., 2019), serta PCR (Putro et al., 2016).

\section{Pemeriksaan Hematologi dan Kimia Darah}

Kelainan hematologi yang umum ditunjukkan pada mayoritas anjing yang mengalami leptospirosis yaitu leukositosis. Pada fase leptospiraemia, leukopenia terkadang dapat dijumpai. Diferensial leukosit umumnya menunjukkan neutrofilia, limfopenia dan monositosis. Trombositopenia ringan hingga berat dapat disebabkan oleh 
aktivasi, adhesi dan agregasi trombosit ke endotelium, fagositosis sel Kupffer, kerusakan platelet yang dimediasi oleh imun atau sekuestrasi limpa. Pada sekitar $50 \%$ dari anjing dengan leptospirosis dijumpai gejala anemia ringan sampai sedang yang disebabkan karena kehilangan darah melalui saluran pernapasan atau pencernaan. Hemolisis karena efek racun leptospira lebih jarang terjadi pada anjing dibandingkan pada sapi (Schuller et al., 2015). Pada kasus leptospirosis, konsentrasi urea dan kreatinin darah meningkat pada sebagian besar anjing. Kerusakan liver dapat terjadi pada leptospirosis, ditunjukkan dengan adanya peningkatan aktivitas dari serum ALT, AST, ALP serta hiperbilirubinemia yang umumnya terjadi bersamaan dengan azotaemia (Geisen et al., 2007). Hasil pemeriksaan hematologi pada anjing dengan diagnosa dugaan leptospirosis di RSHP UB, Malang, menunjukkan anemia normositik hipokromik, leukositosis dan neutrofilia. Sel eritrosit hipokromik berbentuk anisositosis dan berwarna pucat. Pemeriksaan kimia darah menunjukkan adanya peningkatan total bilirubin, ALP dan BUN. Sedangkan total protein, albumin dan kreatinin menunjukkan penurunan (Prasetyo dan Pamungkas, 2018). Pemeriksaan hematologi dan kimia darah tidak dapat digunakan untuk menentukan diagnosis definitif dari leptospirosis, namun pemeriksaan ini dapat digunakan untuk mengetahui status perkembangan penyakit dan kesehatan pasien sehingga dapat membantu dalam pemberian terapi suportif yang tepat untuk meningkatkan peluang kesembuhan pasien.

\section{Pemeriksaan Elektrolit}

Kelainan elektrolit pada kasus leptospirosis pada anjing umumnya berupa hipokalemia dan hiperkalemia, hiperfosfatemia dan hipofosfatemia, hiponatremia dan hipokloremia. Perubahan ini biasanya terjadi selaras dengan derajat kerusakan fungsi ginjal dan gastrointestinal. Hipokalemia dapat terjadi karena kerusakan fungsi ginjal atau gastrointestinal (Goldstein et al., 2006). Pemeriksaan elektrolit pada kasus leptospirosis dilakukan untuk mengetahui status elektrolit pasien, sehingga dapat dilakukan pemberian terapi suportif yang tepat dan untuk meningkatkan peluang kesembuhan pasien.

\section{Urinalisis}

Urinalisis menunjukkan isosthenuria pada sebagian besar anjing dengan leptospirosis, namun hyposthenuria juga dapat terjadi. Glukosuria sekunder, hematuria dan piuria dapat terjadi, akibat cedera tubular (Kohn et al., 2010). Proteinuria muncul di sebagian besar kasus leptospirosis pada anjing. Elektroforesis protein urin pada anjing penderita leptospirosis, menunjukkan berat molekul tinggi yang konsisten dengan kerusakan glomerulus dan/atau protein yang memiliki berat molekul rendah yang konsisten dengan protein yang berasal dari tubulus ginjal (Mastrorilli et al., 2007). Pemeriksaan urin menggunakan mikroskop cahaya tidak selalu menemukan Leptospira sp (Budihal and Perwez, 2014). Fibrin dan protein filamen dalam sampel urin dapat disalahartikan sebagai leptospira. 


\section{Kultur Bakteri}

Sampel untuk kultur Leptospira sp. dari anjing yang diduga leptospirosis dapat berupa urin atau sampel darah yang dimasukkan pada tabung yang berisi media cair. Media albumin asam oleat adalah media yang paling umum digunakan untuk kultur Leptospira sp. Media ini terdiri dari amonium klorida, tiamin, disodium fosfat dan monopotasium fosfat serta berbagai faktor yang memperkaya media termasuk Tween 80 dan albumin. Antibiotik seperti rifampisin, neomisin, aktidion dapat ditambahkan ke media untuk isolasi bakteri secara selektif, pada sampel yang terkontaminasi (Miraglia et al., 2009). Metode kultur dapat memberikan hasil yang sangat akurat, namun membutuhkan proses panjang. Hal ini dikarenakan Leptospira sp. membutuhkan waktu yang sangat lama untuk membelah, yaitu sekitar 6-8 jam dan keseluruhan waktu yang dibutuhkan untuk kultur dapat memakan waktu hampir 3 bulan untuk tumbuh. Metode ini tidak efektif untuk diagnosis kasus yang membutuhkan penanganan pasien secara cepat, namun metode ini dapat digunakan untuk penelitian atau riset. Leptospira sp. adalah organisme yang sangat menular, maka dari itu perlu ditangani dengan sangat hati-hati, karena ada risiko infeksi yang didapat di laboratorium dengan teknik ini (Budihal and Perwez, 2014).

\section{Microscopic Agglutination Test (MAT)}

Metode MAT merupakan uji yang paling umum digunakan di Indonesia. Pemeriksaan MAT di Indonesia dapat dilakukan di Balai Besar Penelitian
Veteriner, Bogor. Pengujian ini dapat mendiagnosa paparan Leptospira sp. pada anjing yang tidak menunjukkan gejala leptospirosis, namun pengujian ini tidak dapat mengetahui apakah hewan sebagai karier atau tidak dikarenakan titer antibodi bisa rendah pada hewan yang terinfeksi secara kronis (Arent et al., 2013). Prinsip MAT yaitu kemampuan pengenceran serial serum pasien untuk menggumpalkan serovar leptospira hidup secara in vitro (Levett et al., 2001)(Musso and La Scola, 2013). Pembacaan hasil MAT dilakukan dengan menggunakan mikroskop medan gelap. Mikroskop medan gelap merupakan mikroskop yang menggunakan lensa kondensor untuk memantulkan cahaya sehingga objek yang diamati menjadi lebih terang dan area disekitarnya menjadi lebih gelap. Titik akhir pembacaan MAT adalah 50\% aglutinasi yang artinya 50\% leptospira tidak teraglutinasi, yang disebut dengan titer antibodi (Mulyani et al., 2017).

Titer MAT diperoleh dengan menguji berbagai pengenceran serum dengan serovar positif. Sampel dinyatakan positif terhadap serovar leptospira apabila menunjukkan titer lebih atau sama dengan 1:100. Uji ini dianggap sebagai gold standard (Chirathaworn et al., 2014). Pengujian serologis menggunakan metode MAT dari sampel darah leptospirosis pada anjing dalam fase akut memiliki spesifisitas mencapai $100 \%$, sensitivitas $50 \%$, dan akurasi $64 \%$. Namun pengujian serologis sampel darah pasien yang sembuh memiliki spesifisitas 92\%, sensitivitas 100\%, dan akurasi 98\%. Pengujian MAT cukup akurat untuk diagnosis leptospirosis pada anjing, namun memiliki sensitivitas rendah untuk 
diagnosis pada fase infeksi akut (Fraune et al., 2013). Selain itu, selama fase akut antibodi yang meningkat mungkin tidak spesifik (Jimenez-Coello et al., 2008). Uji MAT juga mungkin menunjukkan hasil negatif pada tahap awal penyakit dikarenakan belum terbentuk antibodi pada tubuh inang, sehingga pengujian harus dilakukan lebih dari satu kali untuk meneguhkan diagnosa (Budihal and Perwez 2014). Uji MAT umumnya dilakukan pada semua jenis serovar Leptospira sp. yang bersirkulasi pada suatu daerah sehingga membutuhkan biaya yang cukup mahal.

\section{Polymerase Chain Reaction (PCR)}

Metode PCR bertujuan untuk mendeteksi adanya DNA Leptospira. Pengujian pada sampel klinis menggunakan primer yang berasal dari sekuen DNA spesifik Leptospira (Sykes et al., 2011). Pendeteksian leptospirosis dikembangkan dengan menggunakan beberapa target gen. Beberapa gen digunakan sebagai target untuk mendeteksi genus bakteri Leptospira misalnya gen $16 \mathrm{~S}$ rRNA, lipL32, LigA dan LigB. Sekuen gen RRS yang menyandi 16S rRNA merupakan sekuen gen paling umum digunakan untuk deteksi leptospirosis (Putro et al., 2016). Melalui uji PCR, Leptospira sp. dapat dengan mudah dideteksi dari sampel urin atau sampel darah pada tahap awal penyakit dengan cara yang lebih cepat dibandingkan dengan teknik konvensional seperti kultur bakteri (Shafighi et al., 2014). Prosedur real-time PCR (RT-PCR) telah dikembangkan untuk deteksi Leptospira sp. dan mampu memberikan hasil diagnosis segera setelah materi DNA diamplifikasi, dibandingkan dengan PCR konvensional (Villumsen et al., 2010). Uji PCR pada pengujian sampel urin anjing terduga leptospirosis mempunyai sensitivitas $100 \%$ dan spesifisitas 88,3\% (Harkin et al., 2003).

Pengujian leptospirosis menggunakan PCR memiliki kelemahan terutama saat menggunakan spesimen urin (Fink et al., 2015). Hal ini disebabkan karena primer dapat mengikat ke situs yang tidak spesifik, sehingga menunjukkan hasil positif palsu. Guna mendapatkan hasil yang lebih akurat, penggunaan teknik molekuler PCR dan serologis ELISA lebih menjadi pilihan apabila dibandingkan dengan MAT (Gasem et al., 2020). Pemeriksaan PCR terhadap leptospirosis dapat dilakukan di Laboratorium Bakteriologi, Balai Besar Penelitian dan Pengembangan Vektor dan Reservoir Penyakit (B2P2VRP), Salatiga, Jawa Tengah (Putro et al., 2016).

\section{Enzyme-Linked Immunosorbent Assay (ELISA)}

ELISA merupakan salah satu metode uji serologis yang digunakan untuk mendiagnosis leptospirosis melalui deteksi antileptospira IgM. Antileptospira IgM dapat dideteksi 4 atau 6 hari setelah timbulnya gejala klinis (Lizer et al., 2017). Deteksi IgM biasanya menggunakan antigen spesifik genus Leptospira. Selain itu metode ELISA juga dapat dilakukan untuk mendeteksi IgG. Antibodi IgG dapat terdeteksi mulai dua minggu setelah infeksi dan bertahan sampai waktu yang lama (Kusmiyati et al., 2005). ELISA mempunyai sensitifitas yang lebih tinggi dibandingkan dengan MAT (Sumanth et al., 2013). Sensitivitas ELISA mencapai $98,6 \%$ dan 
spesifisitasnya 95,8\% (Jimenez-Coello et al.,, 2008). Metode pengujian ini lebih efisien karena membutuhkan waktu hanya 2-4 jam. Meskipun lebih efisien, namun tingkat antibodi yang masih rendah atau belum ada selama fase awal infeksi dapat menyebabkan diagnosis negatif palsu (Rosa et al., 2017).

\section{PREVALENSI LEPTOSPIROSIS PADA ANJING DI INDONESIA}

Prevalensi leptospirosis pada anjing di Indonesia berkisar antara 13,8\%-44\% dengan varian leptospirosis antara lain serovar Ichterohaemorrhagiae, Celledoni, Canicola, Pyrogenes, Cynopteri, Rachmati, Bataviae, Javanica, Grippotyphosa dan Tarrasovi. Pada kurun waktu 2002-2004, prevalensi kejadian leptospirosis pada anjing di Indonesia sebesar 24,6\% (Kusmiyati et al., 2005). Seroprevalensi leptospirosis pada anjing di kota Denpasar yaitu sebesar 18,2\% $(\mathrm{n}=55)$ dengan varian antara lain serovar Canicola, Celledoni, Cynopteri dan Ichterohemorrhagiae (Mutawadiah et al., 2015). Seroprevalensi leptospirosis pada anjing di Daerah Istimewa Yogyakarta yaitu sebesar 15-44\% dengan serovar antara lain Ichterohaemorrhagiae, Celledoni, Canicola, Pyrogenes, Cynopteri, Rachmati, Bataviae, Javanica, Grippotyphosa dan Tarrasovi (Mulyani et al., 2017). Leptospirosis pada anjing di kota Semarang yaitu sebesar 13,8\% $(\mathrm{n}=29)$ (Putro et al., 2016).

\section{FAKTOR RISIKO LEPTOSPIROSIS PADA ANJING}

Studi faktor risiko leptospirosis pada anjing di Indonesai belum pernah dilaporkan. Studi di negara lain menunjukkan bahwa kejadian wabah leptospirosis pada daerah endemik umumnya berkaitan dengan musim. Hujan dengan intensitas tinggi dapat menghanyutkan Leptospira sp. kedalam air. Leptospirosis di wilayah Asia-Pasifik, dianggap sebagai penyakit berperantara air. Lingkungan yang optimum untuk Leptospira sp. bertahan hidup dan melakukan perkembangbiakan yaitu pada kondisi lembab, temperatur optimum berkisar $25^{\circ} \mathrm{C}$, dan $\mathrm{pH}$ netral. Kondisi tersebut umum di negara tropik dan terjadi hampir sepanjang tahun. Anjing yang melakukan kontak langsung dengan tikus memiliki risiko lebih besar terjangkit leptospirosis dibanding individu yang tidak melakukan kontak langsung dengan tikus (Goldstein, 2010). Anjing yang sering berada di area kotor, hidup di luar rumah, serta memakan daging mentah memiliki risiko yang lebih besar untuk terjangkit leptospirosis dibandingkan anjing rumahan (Meeyam et al., 2006). Tingkat infeksi Leptospirosis pada anjing relatif lebih tinggi ditemukan pada anjing jantan jika dibandingkan dengan anjing betina (Ward et al., 2004). Hal ini disebabkan oleh aktivitas seksual anjing jantan yang suka mengendus dan menjilat vulva anjing betina, memungkin anjing jantan berisiko kontak dengan urin yang mengandung Leptospira (Winaya et al., 2018). Rentang usia anjing yang terjangkit leptospirosis yaitu antara 4-7 tahun (Ward et al., 2004)

\section{PENCEGAHAN}

Pencegahan leptospirosis pada anjing bisa dilakukan dengan vaksinasi pada usia 
tiga bulan (Goldstein, 2010). Anjing yang hidup di daerah rawan leptospira bisa divaksin rutin tahunan (Sykes et al., 2011). Vaksin terbukti dapat melindungi anjing setidaknya selama 12 bulan (Klaasen et al., 2003). Namun vaksinasi terhadap leptospira dinilai masih kurang efektif dikarenakan vaksin komersil yang beredar di Indonesia umumnya hanya mengandung serovar Canicola dan Icterohaemorrhagiae (bivalent), sehingga memungkinkan serovar lainnya untuk menginfeksi. Kandungan vaksin sebaiknya terdiri atas serovar leptospira yang dominan pada suatu daerah (Koizumi et al., 2013). Vaksin quadrivalent telah tersedia di Amerika dengan penambahan serovar Pomona dan Grippotyphosa.

Selain melalui vaksinasi, penularan Leptospira sp. pada anjing peliharaan dapat dicegah dengan membatasi kontak langsung dengan hewan-hewan reservoir seperti tikus, sapi, babi, kuda dan domba (Goldstein, 2010). Anjing juga perlu dihindarkan dari berkontak dengan sumber penularan potensial seperti genangan-genangan air serta mengeliminasi tikus di sekitar rumah. Eliminasi Leptospira sp. pada lingkungan dapat dilakukan dengan iradiasi UV dan larutan desinfektan, seperti iodine, hidrogen peroksida, dan larutan amonium kuaterner (Sykes et al., 2011).

\section{PENGOBATAN}

Pengobatan leptospirosis pada anjing dapat berupa antibiotik dan terapi suportif. Terapi pada anjing penderita leptospirosis yaitu antibiotik berspektrum luas misalnya ampisilin, doksisiklin, eritromisin, tetrasiklin, streptomisin, dan penisilin (Ellis, 2015). Penisilin, ampisilin, amoksisilin dan tetrasiklin dengan dosis tinggi diyakini efektif pada fase leptospiremia. Pemberian penisilin atau turunannya secara intravena umum digunakan pada fase ini. Pemberian amoksisilin dapat dilakukan selama 14 hari. Pemberian doksisiklin selama 14 hari dilakukan setelah penisilin atau turunannya (Claus et al., 2008). Doksisiklin lebih efektif digunakan pada fase leptospiruria agar pembersihan bakteri pada tubulus ginjal lebih optimum (Sykes et al., 2011). Leptospirosis merupakan penyakit sistemik yang mampu mengakibatkan kerusakan berbagai organ, maka dari itu rencana terapeutik harus didasarkan pada keseluruhan evaluasi klinis dan klinikopatologi untuk menghindari keputusan terapeutik yang tidak tepat (Schuller et al., 2015).

\section{KESIMPULAN}

Anjing merupakan salah satu hewan reservoir leptospira dan sumber penularan pada manusia. Prevalensi leptospirosis pada anjing di Indonesia 13,8\%-44\% dengan varian leptospirosis antara lain serovar Ichterohaemorrhagiae, Celledoni, Canicola, Pyrogenes, Cynopteri, Rachmati, Bataviae, Javanica, Grippotyphosa dan Tarrasovi. Diagnosis definitif terhadap leptospirosis pada anjing di Indonesia umumnya menggunakan MAT yang merupakan gold standard pengujian Leptospira, namun kombinasi Uji PCR dan ELISA lebih cepat serta memiliki sensitivitas yang lebih tinggi. Pencegahan terhadap 
leptospirosis dapat dilakukan dengan cara vaksinasi, penggunaan desinfektan secara rutin dan mencegah anjing kontak langsung dengan hewan reservoir seperti tikus. Pengobatan leptospirosis pada anjing dapat berupa terapi antimikroba dan terapi suportif.

\section{DAFTAR PUSTAKA}

Adin, C. A. and Cowgill, L. D. 2000. Treatment and outcome of dogs with leptospirosis: 38 cases (1990-1098). Journal of the American Veterinary Medical Association. 216(3):371-375.

Adler, B. and Klaasen, E. 2015. Recent advances in canine leptospirosis: focus on vaccine development. VMRR.6:245-260.

Arent, Z. J., Andrews, S., AdamamaMoraitou, K., Gilmore, C., Pardali, D., Ellis, W.A. 2013. Emergence of novel Leptospira serovars: A need for adjusting vaccination policies for dogs? Epidemiology and Infection. 141(6):1148-1153.

Benacer, D., Who, P. Y., Zain, S. N. M., Amran, F., Thong, K. L. 2013. Pathogenic and saprophytic Leptospira species in water and soils from selected urban sites in peninsular Malaysia. Microbes and Environments. 28(1):135-140.

Bierque, E., Thibeaux, R., Girault, D., Soupé-Gilbert, M. E., Goarant, C.. 2020. A systematic review of Leptospira in water and soil environments. PLoS ONE. 15(1):122.

Budihal, S. V. and Perwez, K. 2014. Leptospirosis diagnosis: Competancy of various laboratory tests. Journal of Clinical and Diagnostic Research. 8(1):199-202.
Bulach, D. M., Zuerner, R. L., Wilson, P., Seemann, T., McGrath, A., Cullen, P. A., Davis, J., Johnson, M., Kuczek, E., Alt, D. P, et al., 2006. Genome reduction in Leptospira borgpetersenii reflects limited transmission potential. Proceedings of the National Academy of Sciences. 103(39):14560-14565.

Cagliero, J., Villanueva, S. Y. A. M, Matsui, M. 2018. Leptospirosis pathophysiology: Into the storm of cytokines. Frontiers in Cellular and Infection Microbiology. 8(JUN):1-8.

Chaiwattanarungruengpaisan, S., Suwanpakdee, S., Sangkachai, N., Chamsai, T., Taruyanon, K., Thongdee, M. 2018. Potentially pathogenic leptospira species isolated from a waterfall in Thailand. Japanese Journal of Infectious Diseases. 71(1):65-67.

Chirathaworn, C., Inwattana, R., Poovorawan, Y., Suwancharoen, D. 2014. Interpretation of microscopic agglutination test for leptospirosis diagnosis and seroprevalence. Asian Pacific Journal of Tropical Biomedicine. 4(Suppl 1):S162-S164.

Claus, A., Van De Maele, I., Pasmans, F., Gommeren, K., Daminet, S. 2008. Leptospirosis in dogs: A retrospective study of seven clinical cases in Belgium. Vlaams Diergeneeskundig Tijdschrift. 77(4):259-263.

Ellis, W.A. 2015. Animal Leptospirosis. Volume ke-387. Heidelberg : Springer Berlin Heidelberg.

Evangelista, K. V. and Coburn, J. 2011. Leptospira as an emerging pathogen: a review of its biology, pathogenesis and host immune responses. Future Microbiol. 5(9):1413-1425.

Fink, J. M., Moore, G. E., Landau, R., Vemulapalli, R. 2015. Evaluation of three $5^{\prime}$ exonuclease-based real-time 
polymerase chain reaction assays for detection of pathogenic Leptospira species in canine urine. Journal of Veterinary Diagnostic Investigation. 27(2):159-166.

Gasem, M. H., Hadi, U., Alisjahbana, B., Tjitra, E., Hapsari, M. M. D. E. A. H., Lestari, E. S., Aman, A. T., Lokida, D., Salim, G., Kosasih, H., et al., 2020. Leptospirosis in Indonesia: Diagnostic challenges associated with atypical clinical manifestations and limited laboratory capacity. $B M C$ Infectious Diseases. 20(1):1-11.

Geisen, V., Stengel, C., Brem, S., Müller, W., Greene, C., Hartmann, K. 2007. Canine leptospirosis infections Clinical signs and outcome with different suspected Leptospira serogroups (42 cases). Journal of Small Animal Practice. 48(6):324328.

Goldstein, R. E. 2010. Canine Leptospirosis. Veterinary Clinics of North America-Small Animal Practice. 40(6):1091-1101.

Goldstein, R. E., Lin, R. C., Langston, C. E., Scrivani, P. V., Erb, H. N., Barr, S. C. 2006. Influence of infecting serogroup on clinical features of leptospirosis in dogs. Journal of Veterinary Internal Medicine. 20(3):489-494.

Greene, C. E. 2012. Infectious Diseases of the Dog and Cat. Ed ke-4. St. Louis. Missouri. USA: Saunders Elsevier Inc.

Greenlee, J. J., Alt, D. P., Bolin, C. A., Zuerner, R. L., Andreasen, C. B. 2005. Experimental canine leptospirosis caused by Leptospira interrogans serovars pomona and bratislava. American Journal of Veterinary Research. 66(10):18161822.
Harkin, K. R., Roshto, Y. M., Sullivan, J T., Purvis, T. J., Chengappa, M. M. 2003. Comparison of polymerase chain reaction assay, bacteriologic culture, and serologic testing in assessment of prevalence of urinary shedding of leptospires in dogs. Journal of the American Veterinary Medical Association. 222(9):12301233.

Jimenez-Coello, M., Vado-Solis, I., Cárdenas-Marrufo, M. F., RodríguezBuenfil, J. C., Ortega-Pacheco, A. 2008. Serological survey of canine leptospirosis in the tropics of Yucatan Mexico using two different tests. Acta Tropica. 106(1):22-26.

Johnson, D. I. and Johnson, D. I. 2018. Leptospira spp. Bacterial Pathogens and Their Virulence Factors. 289294.

Klaasen, H. L. B. M., Molkenboer, M. J. C. H., Vrijenhoek, M. P., Kaashoek, M. J. 2003. Duration of immunity in dogs vaccinated against leptospirosis with a bivalent inactivated vaccine. Veterinary Microbiology. 95(12):121-132.

Ko, A. I., Goarant, C., Picardeau, M. 2009. Leptospira: the dawn of the molecular genetics era for an emerging zoonotic pathogen. Nat Rev Microbiol. 7(10):736-747.

Kohn, B., Steinicke, K., Arndt, G., Gruber, A. D., Guerra, B., Jansen, A., Klopfleisch, R., Lotz, F., Luge, E., No, K. 2010. Pulmonary Abnormalities in Dogs with Leptospirosis. $J$ Vet Intern Med. 24(6):1277-1282.

Koizumi, N., Muto, M. M., Akachi, S., Okano, S., Yamamoto, S., Horikawa, K., Harada, S., Funatsumaru, S., Ohnishi, M. 2013. Molecular and serological investigation of Leptospira and leptospirosis in dogs in Japan. 
Journal of Medical Microbiology. 62(PART4):630-636.

Fraune, K.C., Schweighauser, A., Francey, T. 2013. Evaluation of the diagnostic value of serologic microagglutination testing and a polymerase chain reaction assay for diagnosis of acute leptospirosis in dogs in a referral center. Journal of the American Veterinary Medical Association. 242(10):1373-1380.

Kurilung, A., Chanchaithong, P., Lugsomya, K., Niyomtham, W., Wuthiekanun, V., Prapasarakul, N. 2017. Molecular detection and isolation of pathogenic Leptospira from asymptomatic humans, domestic animals and water sources in Nan province, a rural area of Thailand. Research in Veterinary Science. 115(March):146-154.

Kusmiyati, Noor, S. M., Supar. 2005. Animal and human Leptospirosis in Indonesia. Wartazoa. 15(4):213-9.

Levett, P. N., Branch, S. L., Whittington, C. U., Edwards, C. N., Paxton, H. 2001. Two methods for rapid serological diagnosis of acute leptospirosis. Clinical and Diagnostic Laboratory Immunology. 8(2):349351.

Lizer, J., Grahlmann, M., Hapke, H., Velineni, S., Lin, D., Kohn, B. 2017. Evaluation of a rapid IgM detection test for diagnosis of acute leptospirosis in dogs. Veterinary Record. 180(21):517-521

Major, A., Schweighauser, A., Francey, T. 2014. Increasing incidence of canine leptospirosis in Switzerland. International Journal of Environmental Research and Public Health. 11(7):7242-7260.

Mastrorilli, C., Dondi, F., Agnoli, C., Elena, T. M., Vezzali, E., Gentilini, F.
2007. Clinicopathologic Features and Outcome Predictors of Leptospira Interrogans Australis Serogroup Infection in Dogs: A Retrospective Study of 20 Cases (2001-2004). Journal of Veterinary Internal Medicine. 21(1):3-10

Matthias, M. A., Ricaldi, J. N., Cespedes, M., Diaz, M. M., Galloway, R. L., Saito, M., Steigerwalt, A. G., Patra, K. P., Ore, C. V., Gotuzzo, E., et al., 2008. Human leptospirosis caused by a new, antigenically unique Leptospira associated with a Rattus species reservoir in the Peruvian Amazon. PLoS Neglected Tropical Diseases. 2(4):1-12.

Meeyam, T., Tablerk, P., Petchanok, B., Pichpol, D., Padungtod, P. 2006. Seroprevalence and risk factors associated with leptospirosis in dogs. Southeast Asian Journal of Tropical Medicine and Public Health. 37(1):148-153.

Miraglia, F., De Moraes, Z. M., Melville, P. A., Dias, R. A., Vasconcellos, S. A. 2009. Emjh medium with 5fluorouracil and nalidixic acid associated with serial dilution technique used to recover leptospira spp from experimentally contaminated bovine semen. Brazilian Journal of Microbiology. 40(1):189193.

Mishima, N., Tabuchi, K., Kuroda, T., Nakatani, I., Lamaningao, P., Miyake, M, Kanda, S., Koizumi, N., Nishiyama, T. 2013. The first case in Japan of severe human leptospirosis imported from Vietnam. Tropical Medicine and Health. 41(4):171-176.

Mohammed, H., Nozha, C., Hakim, K., Abdelaziz, F. 2011. LEPTOSPIRA: Morphology, Classification and Pathogenesis. Journal of Bacteriology \& Parasitology. 02(06):6-9. 
Mulyani, G. T., Hartati, S., Santoso, Y., Kurnia, K., Pramono, A. B., Wirapratiwi, D. K. 2017. Kejadian Leptospirosis pada Anjing di Daerah Istimewa Yogyakarta. Jurnal Veteriner. 18(3):403-408.

Mulyani, G. T., Hartati, S., Wuryastuty, H., Tjahajati, I., Yuriadi, Y., Widiyono, I., Yanuartono, Y., Purnamaningsih, H., Indarjulianto, S., Raharjo, S., et al., 2019. Identifikasi Serovar Penyebab Leptospirosis pada Anjing di Yogyakarta. Jurnal Sain Veteriner. 37(2):227-231.

Musso, D. and La Scola, B. 2013. Laboratory diagnosis of leptospirosis: A challenge. Journal of Microbiology, Immunology and Infection. 46(4):245-252.

Mutawadiah, Puja I. K. P., Dharmawan N. S. 2015. Seroprevalensi Leptospirosis pada Anjing Kintamani di Bali Seroprevalence of Leptospirosis in Kintamani Dog in Bali. Jurnal Ilmu dan Kesehatan Hewan. 3(2):41-44.

Prasetyo, D. and Pamungkas, K. N. I. N. 2018. Suspect leptospirosis pada anjing lokal mix. ARSHI Veterinary Letters. 2(4):75-76.

Pui, C. F., Bilung, L. M., Apun, K., Su'ut, L. 2017. Diversity of Leptospira spp. in Rats and Environment from Urban Areas of Sarawak, Malaysia. Journal of Tropical Medicine. 2017:1-8.

Putro, D. B. W., Ristiyanto, R., Mulyono, A., Handayani, F. D., Joharina, A. S. 2016. Deteksi Leptospira Patogenik pada Urin Anjing dengan Polymerase Chain Reaction (PCR) di Kota Semarang. Vektora: Jurnal Vektor dan Reservoir Penyakit. 8(1):7-12.

Ramadhani, T. dan Yunianto, B. 2012. Reservoir dan Kasus Leptospirosis di Wilayah Kejadian Luar Biasa.
Kesmas: National Public Health Journal. 7(4):162-168.

Rosa, M. I., dos Reis, M. F., Simon, C., Dondossola, E., Alexandre, M. C., Colonetti, T., Meller, F. O. 2017. ELISA IgM para diagnóstico de leptospirose: Revisão sistemática e meta-análise. Ciencia e Saude Coletiva. 22(12):4001-4012.

Saito, M., Villanueva, S. Y. A. M., Chakraborty, A., Miyahara, S., Segawa, T., Asoh, T., Ozuru, R., Gloriani, N. G., Yanagihara, Y., Yoshida, S. I. 2013. Comparative analysis of Leptospira strains isolated from environmental soil and water in the Philippines and Japan. Applied and Environmental Microbiology. 79(2):601-609.

Samrot, A. V., Sean, T. C, Bhavya, K. S., Sahithya, C. S., Chandrasekaran, S., Palanisamy, R., Robinson, E. R., Subbiah, S. K., Mok, P. L. 2021. Leptospiral infection, pathogenesis and its diagnosis - a review. Pathogens. 10(2):1-30.

dos Santos, L. F., Guimarães, M. F., de Souza, G. O., da Silva, I. W. G., Santos, J. R., Azevedo, S. S., Labruna, M. B., Heinemann, MB., Horta, M. C. 2017. Seroepidemiological survey on Leptospira spp. infection in wild and domestic mammals in two distinct areas of the semi-arid region of northeastern Brazil. Tropical Animal Health and Production. 49(8):17151722.

Schuller, S., Francey, T., Hartmann, K., Hugonnard, M., Kohn, B., Nally, J. E., Sykes, J. 2015. European consensus statement on leptospirosis in dogs and cats. Journal of Small Animal Practice. 56(3):159-179.

Shafighi, T., Zahraei, Salehi, T., Abdollahpour, G., Asadpour, L., 
Akbarein, H., Salehzadeh, A. 2014. Molecular detection of Leptospira spp. in the urine of cattle in northern Iran. Iranian Journal of Veterinary Research. 15(4):402-405.

Sumanth, K. R., Pillai, R. M., Mukhopadhyay, H. K., Antony, P. X., Thanislass, J., Vivek, S. V. M., Vishnupriya $\quad$ S. 2013. Seroepidemiology of canine leptospirosis by iELISA and MAT. Veterinary World. 6(11):926-930.

Sykes, J. E., Hartmann, K., Lunn, K. F., Moore, G. E., Stoddard, R. A., Goldstein, R. E. 2011. 2010 ACVIM Small Animal Consensus Statement on Leptospirosis: Diagnosis, Epidemiology, Treatment, and Prevention. Journal of Veterinary Internal Medicine. 25(1):1-13.

Thibeaux, R., Geroult, S., Benezech, C., Chabaud, S., Soupé-Gilbert, M. E., Girault, D., Bierque, E., Goarant, C. 2017. Seeking the environmental source of Leptospirosis reveals durable bacterial viability in river soils. PLoS Neglected Tropical Diseases. 11(2):1-14.

Townsend, W. M., Stiles, J., Krohne, S. G. 2006. Leptospirosis and panuveitis in a dog. Veterinary Ophthalmology. 9(3):169-173.

Villumsen, S., Pedersen, R., Krogfelt, K. A., Jensen, J. S. 2010. Expanding the diagnostic use of PCR in leptospirosis: Improved method for DNA extraction from blood cultures. PLoS ONE. 5(8):1-7.

Ward, M. P., Guptill, L. F., Prahl, A., Wu, C. C. 2004. Serovar-specific prevalence and risk factors for leptospirosis among dogs: 90 Cases (1997-2002). Journal of the American Veterinary Medical Association. 224(12):1958-1963.
Winaya, I. B. O., Berata, I. K., Kardena, I. M., Adi, A. A. A. M., Rompis, A. L. T. 2018. Gambaran Histopatologi Hati dan Ginjal Anjing Terduga Leptospirosis di Kota Denpasar. Jurnal Veteriner. 19(2):298-302. 